\title{
MANIFESTATION OF GENDER INEQUALITIES IN STUDENT ORGANIZATIONS
}

\author{
Andhita Risko Faristiana \\ IAIN Ponorogo \\ andhitarisko@iainponorogo.ac.id
}

\begin{abstract}
Gender inequalities is still an endless problem, even though everyone knows that men and women are different. The culture that is socialized by the family is the beginning of the occurrence of gender injustice in society. Then it continues when a child grows up in the surrounding environment, especially where they received formal education. This article discusses forms of gender inequalities experienced by college students in participating in organizations on campus. This research is descriptive qualitative research. The purpose of this research is to explore the patriarchal culture that views women as the second gender, followed by regional culture that makes the views more deeply rooted in society, especially in student organizations. Javanese culture constructs society that women must be under men. Millennial generation women who should have been freed from the shackles of patriarchy are still experiencing subordination in college organizations. In the organizational structure, women are never made leaders and in the committee, they always get tasks in the domestic area, not the public.
\end{abstract}

Keywords : Patriarchy, Subordination, Socialization, Student Organizations.

\begin{abstract}
Abstrak
Ketidaksetaraan gender memang masih menjadi masalah yang tiada habisnya, meski semua orang tahu bahwa laki-laki dan perempuan berbeda. Budaya yang disosialisasikan oleh keluarga merupakan awal dari terjadinya ketidakadilan gender di masyarakat. Kemudian berlanjut ketika seorang anak dibesarkan di lingkungan sekitarnya, terutama di tempat mereka mengenyam pendidikan formal. Artikel ini membahas tentang bentuk-bentuk ketidaksetaraan gender yang dialami mahasiswa dalam mengikuti organisasi di kampus. Penelitian ini merupakan penelitian kualitatif deskriptif. Tujuan dari penelitian ini adalah untuk menggali budaya patriarki yang memandang perempuan sebagai gender kedua, diikuti oleh budaya daerah yang membuat pandangan tersebut semakin mengakar di masyarakat, khususnya di organisasi kemahasiswaan. Budaya Jawa membangun masyarakat bahwa perempuan harus berada di bawah laki-laki. Perempuan generasi milenial yang semestinya terbebas dari belenggu patriarki masih mengalami subordinasi dalam organisasi perguruan tinggi. Dalam struktur organisasi, perempuan tidak pernah dijadikan pemimpin dan dalam kepanitiaan mereka selalu mendapat tugas di wilayah domestik, bukan publik.
\end{abstract}

Kata Kunci : Patriarkhi, Subordinasi, Peradaban, Organisasi Mahasiswa.

\section{INTRODUCTIONS}

In today's society, "gender" is still one of the hot issues in Indonesia. The word gender does not sound foreign to the public. If you hear the word gender, perhaps 
what comes to the mind of the general public, beginner learners must be interpreted as "women's problems". There is still a misunderstanding of the meaning of the term gender in society, including academics. This is the starting point of the problems that occur against gender fighters in Indonesia.

In Indonesia, there are many problems of gender injustice and inequalities because of the doctrine of patriarchy. The patriarchal doctrine that is entrenched in society makes men feel more dominant in all aspects of women's life. This results in incidents or cases that always corner women or the majority of women in the public and domestic sectors. The government responded to concerns about problems experienced by women by establishing the Ministry of Women and Child Protection, which is now led by Yohana Susana Yembise. In the online news, residents of Biak Regency thanked President Joko Widodo for the appointment of bisounwi (female title) Yohana Susana Yambise. ${ }^{1}$

In Javanese culture, the kinship system is reflected in the customary law. The prevailing Javanese customs view every man in the family as having a heavy responsibility ${ }^{2}$. For example, terms in Javanese culture subject the position of women to be lower than that of men. These terms have been ingrained in the hearts of society, and are taken for granted. For example, in Javanese terms, there is a mention of a wife as kanca wingking, which means a friend from behind, a friend in managing household affairs, cooking, washing, a friend taking care of children, and so on. There is another term 'suwarga nunut neraka katut'. This term is also applied to the wife, which means heaven or hell depending on her husband's wife. If the husband goes to heaven, it means that the wife will also go to heaven, but if the husband goes to hell, even though the wife has the right to go to heaven because of good deeds, the wife does not have the right to enter heaven because she has to follow the husband to hell.

The term for wife is not only that, there is a more derogatory term, namely that a wife must be able to give birth, dress up, cooking (which means manak, macak, masak in Indonesian) and some words that start with the letter ' $\mathrm{m}$ '. This means that a wife must be able to provide offspring, must always dress up in front of her husband, and a wife must provide food for her husband. There are other terms attached to a wife, namely kitchen, powder, mattress, well, (in Indonesian language means: dapur, kasur, pupur, sumur) and perhaps many other "ur-ur" suffixes that can be passed on to be attached to women. ${ }^{3}$

1 Antara news. Warga Biar Numfor Gelar Syukuran Pengangkatan Menteri Yohana Yembise (online). Rabu, 5 November 2014. https://papua.antaranews.com/berita/448073/warga-biaknumfor-gelar-syukuran-pengangkatan-menteri-yohana-yembise access date September, 13th 2018 at $5.44 \mathrm{PM}$

2 Madjelis Luhur Taman Siswa, National Personality, Yogyakarta, 1961, p. 42

3 Suwardi Endraswara. Falsafah Hidup Jawa (Yogyakarta: Cakrawala, 2018) 
The effects of the patriarchal doctrine are also influential in the official organization of the government. Structural positions in government organizations and institutions are dominated by men. The perception of society that it is men who are more worthy of being leaders causes the marginalization and subordination of women in obtaining structural positions in their work environment. Men are considered more rational, assertive, and more courageous in making decisions than women. Meanwhile, women are considered less suitable to be leaders because of their gentle nature, prioritizing feelings, and less assertive in making decisions.

Culture creates an image, role, and status for women. The image for a woman is heralded by the culture as being meek, submissive, not arguing, not exceeding that of men. The idealized roles for women are household management, career support for men, obedient wives and mothers who are transgender. In contrast to the image, role, and status for men that are created by culture. The image of a man, among others, is "all-knowing", as a role model who must be "more" than women, rational, and aggressive. The role of a man is idealized as the breadwinner of the family, protector, guard, while the ideal status is the head of the household. Culture still does not really take into account women in the "public" sector only in the "domestic" sector. This ideology has been used by various social institutions and institutions, which have later become social factors regarding the status and roles played by women.

The patriarchal doctrine is accompanied by a religious doctrine which is believed by society as if it legalizes or makes it easier for men to occupy strategic positions in their place of work. Women's access to structural positions is shackled. This is what concerns and disturbs the author to conduct research on gender inequalities that occurs in universities, namely the student organizations of the Faculty of Ushuluddin, Adab, and Da'wah of IAIN Ponorogo.

\section{DISCUSSION}

\section{Methodology}

This research is descriptive qualitative research, which tries to dig up as much information as possible about the issues that are used as research topics by prioritizing verbal data. According to Lexy J. Moleong, citing Bodgan and Taylor's opinion, qualitative methods are research procedures that produce descriptive data in the form of written or spoken words from people and observable behavior. ${ }^{4}$ Then HB. Sutopo said that qualitative research is an activity to answer various questions about how and why (process and meaning) in actual statements covering the extent. ${ }^{5}$ Meanwhile, Sugiyono argues that qualitative research methods are research methods

\footnotetext{
${ }^{4}$ Lexi J. Moleong. Metode Penelitian Kualitatif (Bandung: Rosdakarya, 2005)

5 Sutopo. H.B. Metode Penelitian Kualitatif: Dasar Teori dan Terapannya Dalam Penelitian. Surakarta: Sebelas Maret University Press, 2002
} 
used to examine the conditions of natural objects, (as opposed to experiments) where the researcher is the key instrument, the data collection technique is done by triangulating data and sources, inductive data analysis, and qualitative research results emphasize meaning rather than generalization. ${ }^{6}$

This study analyzed using several theories and concepts, such as:

\section{Patriarchy (Patriarchate)}

The concept of patriarchy was first introduced by Milet in 1970. According to him, men and women are described as being in a dominationsubordination relationship. In essence, patriarchy shows the dominance of men in all aspects of women's lives, then it becomes a culture in the wider community. ${ }^{7}$

In general, patriarchal culture is defined as a system characterized by men or men-oriented. In this system, men who have the power to determine, this condition is considered normal because it is associated with the division of labor based on sex. The existence of this cultural assumption actually gives privileges to the male gender. Therefore this culture does not accommodate equality and balance, wherein this culture the female gender is not taken into account. This culture then embodies the lineage based on the male line. This patriarchal culture has an impact on the relationship between women and men, which in general shows a subordinate relationship, a relationship between top and bottom with male domination. In the theory of patriarchy, it is believed that women are weak creatures and men are strong. ${ }^{8}$

\section{Gender}

This concept mainly discusses the differentiation of men and women based on sociocultural factors. In order not to be confused and confusing, the first thing to be straightened out is the concept of gender and the concept of sex or biological sex. First is the notion of sex or sex which is biologically a characteristic or division of two human sexes that have been biologically determined, permanent (cannot be exchanged between men and women), brought from birth, and is a gift from God, as a man- man or woman or the term simply called "kodrat" (in English: nature). This is followed by the concept of gender, which is a trait inherent in both men and women that is socially and culturally constructed by the community. For example, it is said that women are known to be gentle, beautiful, emotional, or motherly. Meanwhile, men are considered to be assertive, strong, rational, male, powerful. The traits of these traits are interchangeable traits. In essence,

\footnotetext{
${ }^{6}$ Sugiyono. Metode Penelitian Pendidikan Pendekatan Kualitatif, Kuantitatif dan RED. Bandung: Rosdakarya, 2010

7 Partini. Bias Gender dalam Birokrasi (Yogyakarta: Tiara Wacana, 2013)

8 Aggarwal, Sonali. Patriarchy and Women's Subordination dalam Bhartiyam International Journal Of Education \& Research, Volume 5, Issue IV, Page 59-68, September 2016. ISSN: 2277-1255, 2016.
} 
gender discusses more the differentiation of men and women based on sociocultural factors. ${ }^{9}$

In fact, gender differences create various injustices, both for men and especially against women. Gender injustice is manifested as a system and structure in which both men and women become victims of the system. Gender injustice is manifested in various forms of injustice, namely: marginalization or the process of economic impoverishment, subordination/assumption of insignificance in political decisions, the formation of stereotypes/through negative labeling, violence can be physical or verbal, a person's workload is longer and more (double burden), as well as the socialization of gender role values ideology. The manifestations or forms of gender injustice cannot be separated, because they are interrelated and interconnected, affect each other dialectically. ${ }^{10}$

Justice or gender equality refers to the application of social justice in terms of providing equal opportunities for men and women. ${ }^{11}$ This means that men and women have and enjoy the same status; men and women alike have the opportunity to realize their rights and potentials to contribute to the development of education, development, political, economic, social, and cultural health, and can equally enjoy the results of these developments.

One of the real manifestations of gender injustice is subordination. Subordination is the attitude and actions of society that place women in a lower position than men. Subordination is based on the belief that one sex is considered more important or more important than the other sex. ${ }^{12}$

\section{Role theory, status, and socialization}

In sociology, it is very difficult to distinguish between roles and status because they are a unity. Roles and status can only be separated theoretically, but are difficult to distinguish in reality. In Berger's opinion, socialization is a person's learning process to become a participating member of society. Meanwhile, Charlotte Buhler defines socialization as a learning and adjustment process that helps individuals learn how to live and how to think in groups so that they can play a role and function well in their groups. ${ }^{13}$

\section{Javanese culture}

9 Partini. Bias Gender dalam Birokrasi (Yogyakarta: Tiara Wacana, 2013)

10 Nugroho, Riant. Gender dan Strategi Pengarus-utamaannya di Indonesia (Yogyakarta: Pustaka Pelajar, 2011)

11 Abdullah, Amin. Kesetaraan Gender di Perguruan Tinggi Islam (ed. Susilaningsih dan Agus M. Najib). Yogyakarta: Kerjasama UIN Sunan Kalijaga Yogyakarta dengan McGill IAIN Indonesia Social Equity Project, 2004

12 Nurhaeni, Ismi Dwi Astuti. Kebijakan Politik Pro Gender (Surakarta: LPP UNS dan UNS Press, 2009)

13 Partini. Bias Gender dalam Birokrasi (Yogyakarta: Tiara Wacana, 2013) 
Javanese people have a philosophy of life that regulates their society from all aspects, everything has rules. Likewise, between men and women, Javanese culture views men and women differently. The man comes from the word 'man' which means honorable or praiseworthy. In the Javanese tradition of life, men are more respected. Men are always at the front, it is proven that the head of the family is the father. In Java, the patrimonial tradition is still very much felt so that the man or the father becomes the "ruler" of the household. More often than not, the family decision-maker is in the hands of the fathers. Meanwhile, woman or woman has the meaning of 'wani ing tata', which means Javanese women must be able to arrange something she faces, especially in the household matters. ${ }^{14}$

\section{Understanding Gender}

The gender issues are actually have appeared since a long time ago, however, the term 'gender' has only been known recently in society, hence we quite familiar to discuss it, but deep down inside our heart, are we actually know the meaning of the 'gender' term. The word 'gender' heard by the public for the first time in 1986 when Robert Stoller used it as a distinguisher of human's characteristic in their relations with the social and cultural environment which comes from the biological physical characteristics they have. Gender is often associated with women's emancipation and its meaning is contrary to the term 'sex'. This happened because of misunderstanding and the unclear meaning of gender.

The gender itself comes from the English word 'gender' where the meaning is closely associated with sex. The word sex from the English dictionary means the gender of males and females. To distinguish the meaning of gender and sex, we should know the proper meaning of each word in-depth. Sex means the division of human sex in a physical or biological form that is males and females. A male of course has a penis, Adam's apple, and able to produce sperm to fertilize the egg; meanwhile, in female cases, they have breasts for breastfeeding, womb, and produce an egg to be fertilized by the male. Surely those characteristics cannot be combined or replaced between the two sex. This can be said as the nature owned by every human being. Whereas the definition of gender according to Ann Oakley in her book, Sex, Gender, and Society states that gender is utilized as a distinct boundary which is resulted from human culture; therefore, it is not included as the human nature gifted by God. If the sex will remain the same for one's entire life and cannot be changed because it is its nature, then it different from gender which is not included as God's grace and can be changed with the influence of cultural environment and the social interaction they had.

${ }^{14}$ Suwardi Endraswara. Falsafah Hidup Jawa (Yogyakarta: Cakrawala, 2018) 
In more general meaning, gender refers to the faith of how a man and woman behave based on manners, norms, and cultural customs prevailing in their area. Therefore, the gender prevailing in a specific area can be different from the gender prevailing in other areas. The gender that is accepted and prevailed by society is determined based on the perspective and the way society sees it in relation to how a man and a woman should behave. Generally, someone's having male sex will have masculine gender which characterizes as a strong, brave, assertive, and independent personality so that they play a role as a guardian and breadwinner. While someone who is female mostly has feminine gender which characterizes by gentle character so that they play a role as a child caregiver and the one who responsible for the home. But if we rethink it, because gender is manmade which comes from social-cultural perspectives and customs community in such a particular area, then it is possible that the tasks between males and females can be switched according to the culture and society's perspectives in defining the gender term itself.

\section{Gender Inequality ${ }^{15}$}

Gender differences can be caused by gender differences (sex) where women are gentle, irrational, and emotional, while men are rational and mighty. Gender differences are not a problem as long as they do not cause gender inequalities. But in fact, these gender differences have created various injustices for both men and women, for example, women whose reproductive organs can get pregnant, give birth and breastfeed, then emerge gender roles as caregivers and educators of children. Gender inequalities are a structure in which men and women are victims of this is a struct, so that to understand the gender differences that cause injustice it is necessary to look at the various manifestations that can cause this injustice, namely as follows:

a. Marginalization

Marginalization arises as a result of gender views of women. When viewed from the source, the forms of marginalization that often occur against women due to gender differences can come from government policies, beliefs, religious interpretations, traditions and habits, and scientific assumptions. For example, the form of marginalization of women in the household in the form of discrimination against male and female family members which is strengthened by religious interpretations, namely the provision of inheritance rights. In some religious interpretations, the share of inheritance rights for men is twice that of women.

b. Subordination

15 Nugroho, Riant. Gender dan Strategi Pengarus-utamaannya di Indonesia (Yogyakarta: Pustaka Pelajar, 2011) 
Subordination arises as a result of attitudes that place women in an insignificant position. For example, the assumption that women tend to be emotional and irrational so that women cannot be leaders.

c. Stereotypes

Stereotypes, namely negative labeling of a group or gender which can lead to discrimination and various non-existences. One of the sources of this form of stereotype is from the perspective of gender which is generally attached to women so that it causes difficulties, limits, impoverishes, and harms women. For example, the perception of the community that women usually dress up to attract the attention of the opposite sex, so that in cases of violence and sexual harassment even as victims, women are the ones to be blamed.

d. Violence

Violence is an attack on a person's physical and mental integrity against a gender, generally women, as a result of gender differences. Violence towards women occurs mostly due to gender stereotypes. For example, cases of harassment that often occur are not because of the element of beauty but because of the power and gender stereotypes attached to women.

e. Double Burden

Double burden in the opinion of the wider community, the gender role of women in managing the household so that many women bear more domestic workloads than men. For groups in society with suffice economic levels, the domestic workload is often delegated to domestic servants, who are generally women, so that women are victims of gender bias in society.

Manifestations of gender injustice in the form of marginalization, subordination, violence, stereotypes, and workloads have occurred at various levels in society.

1) First, the manifestation of gender injustice occurs at the state level. Many policies, state laws, legislation, and activity programs still reflect some forms of gender injustice.

2) Second, the manifestation of gender injustice occurs in the workplace, organization, and education. Many work regulations, management, organizational policies, and educational curricula still cultivate gender injustice.

3) Third, the manifestation of gender injustice occurs in the customs of a community ethnic group, the cultures of various ethnic groups, and various religious interpretations. Many interactions and decision-making mechanisms in society still reflect gender injustice.

4) Fourth, a form of gender injustice occurs in the household environment. Many families still use fanaticism against gender-biased assumptions starting 
from the decision-making process, division of labor, to interactions between family members.

5) Fifth, a gender injustice that has been rooted in a belief and has become an ideology so that it is difficult to change.

\section{Subordination of Women in Student Organizations}

The patriarchal doctrine has resulted in an imbalance or gap between the number of male and female workers in Indonesia. Data released by the Central Bureau of Statistics (BPS) in 2016 shows that the female labor force participation rate (Tingkat Partisipasi Angkatan Kerja, abbreviated as TPAK) is only 50.77\%, while the male TPAK rate is $81.97 \%$. Other supporting data released by Sakernas in August 2016 showed that only $48.00 \%$ worked compared to the percentage of male workers of $77.29 \%$. This data has proven that there is a division of labor between men and women. Where men are more in the public sector, while women are in the domestic area.

Subordination is the placement of a person in second place, as in the above data which shows that women deserve to be marginalized. Women are considered weak and cannot be used as role models. In women's organizations only as a complement to the organizational structure or committee. Even though an organization has opened up opportunities for women to participate. Even women are allowed to become chairman of an organization, but in reality, very few organizations want to be led by women.

Opportunity is a factor that causes social jealousy between humans. Men have a greater opportunity to lead than women. The facts show that most of the positions are still held by men. This fact is less profitable for women and causes women to always be excluded from positions of office and leadership. Women's participation in organizations is still very low, especially in decision making. The representation of women in organizations is very necessary to change the patriarchal culture. However, the reality is that until now, the opportunity to occupy an important position is still limited by culture, society, and even the law.

The data that the authors get during the study shows that the leaders or heads of organizations in the three student associations are all male. They hold positions as chairman of the HMJ and divisions. Meanwhile, women hold positions as secretary, treasurer, and division members. From the structure of the HMJ board, it can be seen that when choosing a leader, it is expected that a man is a man.

a) The head of the organization is a man

Things like this are very common in organizational structures where a leader is a man. Because he is considered more responsible and does not involve ego and emotion during his leadership. However, the most striking thing is that it starts when the process of determining the chairman of an organization. Mass 
mobilization is often carried out in order to elect male leaders, not infrequently even when the introduction of their vision and mission mentions and associates religious matters. Regarding the leader, it should be a group of men. Not infrequently the process of submitting a candidate in the contestation uses an alternative method so that the Bumbung is not empty, presenting a female rival.

b) The head of the division is coordinated by men, except for the female division.

Women are leaders for women themselves, this statement can be relevant to the appearance in the field, namely that women are able to become leaders even in a division. However, he was in charge of his own people. Because when men hold divisions in a decision, they are considered unable to represent them due to different gender and urgent needs. In this condition, gender discrimination still occurs. Because indirectly these activities describe a woman who is only capable of the same gender.

c) The head of field activity coordination for consumption is chaired by a woman.

Talking about field activities, it cannot be separated from the existence of sections or coordination of sections, one of which is the consumption division. In every field activity held by an organization, of course, it cannot be separated from the issue of consumption. Be it in the form of food or drink. Here the men are mostly members who function as food deliverers and kitchen utensils provider. In addition, the hopes of culture are public property (Geertz, 1992: 15). So, the culture of women taking care of the kitchen is purely from public judgment.

d) Women as Secretaries

The tenacity and intelligence of women are considered a gift to them. In other words, women are considered a gender who has more intelligence than men, even though in several studies it has been shown that the memory capacity of a man's brain is greater than that of a woman. However, women are more talented in everything, and because according to religious principles, women have $90 \%$ lust and 10\% intelligence. So, women are easily prestigious. And this can be a trigger for women to be more diligent in something that they feel is not yet proficient in that field. Therefore, women are considered suitable as secretaries because they are more detailed and detailed even though they are complicated.

e) Women as Treasurers

Women are a gender that has a hedonistic nature, namely a gender who likes commerce, traveling, and even culinary delights. Or in other words, the desire to satisfy oneself related to feelings tends to avoid bad feelings and is more 
focused on how to achieve satisfaction (Sunatra: 2016, 130). And it is sometimes even very consumptive behavior. To fulfill his passion for hedonism. Need means of satisfaction, namely in the form of money and they seem to be stamped in addition to consumptive. women besides the nickname field do not necessarily behave excessively. In fact, a woman is good at managing finances. Because this is a consideration for the public regarding the placement of women's functions as treasurers.

f) The majority of women are members

Apart from several positions that are special and urgent for women, only the best status members in the organization. And used as a complement to management. In this case, the members in question are members who are secondary in nature. In addition, women's subordination is not only rooted in nature but also has a cultural impact on the division of gender functions (Rosaldo, 1974: 23; Ortner, 1974; MacCormack, 1980, as quoted by Moore, 1994: 10-11) As well as physically and emotionally women are under the emotional stability of a man and are more dynamic than a man when looking for solutions in facing problems.

g) Negative stigma of a man in the consumption division of organizational activities

Because men are a gender that is considered superior and has a primary gender position in which the cultural impression of a man is masculine. However, they have to carry out activities that in fact are combined with the activities of the feminine. Even in Javanese science, the man has said 'cupar' or in the sense of doing what is not his nature to do. In the context of Javanese science. Resulting in dissatisfaction and even feeling awkward. Must be related to kitchen stuff. Apart from that in Sie. Male consumption only acts as a means of providing access to food shortages. In fact, what was unexpected was that not all men were able to install and replace LPG gas regulators. Here they are required to be able, whereas we know that this is common and has become a woman's daily diet. The effects are not kidding, among others, the fire caused by the LPG gas valve is not neat and tight with the gas cylinder. Therefore, in this division, it leads to the injustice received by the male gender because they must and are stigmatized to be able to handle all forms of menial and risky work.

\section{CONCLUSION}

The conclusion from the above description is that the manifestations of gender injustice have taken root, starting from the beliefs of each individual, family, to the 
global state level, where dialectically all these manifestations of injustice influence and are interrelated. Manifestations of this injustice are socialized to men and women steadily, then gradually become accustomed to it and in the end, it is believed that gender role as if they are natural. The main support for injustice is a culture of patriarchy where a culture like this places women as the second gender. It's not about discussing patriarchy, sometimes local culture can lead to new perspectives. The student organization is a small area that has the potential to create a process of discrimination against women. In other conditions, the nature and characteristics of women themselves are able to become the main supplier for the formation of the second gender labeling. In other words, subordination is based on the characteristics and real conditions in the field and the daily activities of a woman. However, this does not automatically become the reason for a woman to be in the second gender in an organizational order because in the discussion of religion and the principles of human rights (Hak Asasi Manusia or abbreviated as HAM) have the same rights and obligations as servants and humans. 


\section{REFERENCES}

Abdullah, Amin. Kesetaraan Gender di Perguruan Tinggi Islam (ed. Susilaningsih dan Agus M. Najib). Yogyakarta: Keasama UIN Sunan Kalijaga Yogyakarta dengan McGill IAIN Indonesia Social Equity Project, 2004.

Aggarwal, Sonali. Patriarchy and Women's Subordination dalam Bhartiyam International Journal Of Education \& Research, Volume 5, Issue IV, Page 59-68, September 2016. ISSN: 2277-1255, 2016.

Antara news. Warga Biar Numfor Gelar Syukuran Pengangkatan Menteri Yohana Yembise (online). Rabu, $\quad 5 \quad$ November 2014. https://papua.antaranews.com/berita/448073/warga-biak-numfor-gelarsyukuran-pengangkatan-menteri-yohana-yembise access date September, 13th 2018 at 5.44 PM

Lexi J. Moleong. Metode Penelitian Kualitatif. Bandung: Rosdakarya, 2005.

Naharin, Nikmatun. Subordinasi Perempuan dalam Organisasi Mahasiswa IAIN Tulungangung Tahun 2015 dalam Martabat: Jurnal Perempuan dan Anak, Volume 1 No. 1 hal 175-196 Juli 2018. ISSN: 2581-2076 (p) 2581-0472 (e), 2017.

Nugroho, Riant. Gender dan Strategi Pengarus-utamaannya di Indonesia. Yogyakarta: Pustaka Pelajar, 2011.

Nurhaeni, Ismi Dwi Astuti. Kebijakan Politik Pro Gender. Surakarta: LPP UNS dan UNS Press, 2009.

Partini. Bias Gender dalam Birokrasi. Yogyakarta: Tiara Wacana, 2013.

Suarni, dkk. Subordinasi Anak Perempuan dalam Keluarga dalam Jurnal Equilibrium Pendidikan Sosiologi Volume III No. 1 halaman 29-37 Mei 2015. ISSN e-2477-0221 p2339-240, 2015.

Sugiyono. Metode Penelitian Pendidikan Pendekatan Kualitatif, Kuantitatif dan RED. Bandung: Rosdakarya, 2010.

Sutopo. H.B. Metode Penelitian Kualitatif: Dasar Teori dan Terapannya Dalam Penelitian. Surakarta: Sebelas Maret University Press, 2002.

Suwardi Endraswara. Falsafah Hidup Jawa. Yogyakarta: Cakrawala, 2018

Syafe'i, Imam. Subordinasi Perempuan dan Implikasinya Terhadap Rumah Tangga dalam ANALISIS: Jurnal Studi Keislaman, Volume 15, Nomor 1, halaman 143-166 Juni 2015. ISSN: 2088-9046 (p) 2502-3969 (e), 2015. 